\title{
A NECESSIDADE DE MONITORAMENTO DA SAÚDE DO TRABALHADOR DE ENFERMAGEM
}

Vanda Elisa Andres Felli ${ }^{1}$

A partir da década de 1970 vem sendo incrementada a produção de conhecimento sobre o objeto de estudo Saúde do Trabalhador de Enfermagem.

Os primeiros estudos diagnosticaram, principalmente, a incidência/prevalência dos acidentes de trabalho com essa população, assim como os diferentes tipos de acidentes e riscos ocupacionais a que os trabalhadores de enfermagem estão expostos. Naquele momento, por um lado, foram identificadas as altas frequências dos acidentes de trabalho e a sua caracterização; a ênfase foi aos acidentes com materiais perfurocortantes. Os estudos realizados decepcionam ao não conseguirem captar doenças como hepatites e tuberculose, as quais não eram, sequer, consideradas como relacionadas ao trabalho, ou dificilmente era comprovada essa relação. Além desses agravos, nem mesmo as tão frequentes lombalgias foram relacionadas ao trabalho em enfermagem.

Estudos subsequentes focaram outros problemas de saúde, mostrando que apesar de legalmente não serem considerados como adquiridos no trabalho, a análise das condições de trabalho e a alta frequência dos problemas de saúde e, ainda, os índices de comparação com outros trabalhadores, por si só, evidenciaram essa relação. Dentre esses, estresse, síndrome de Burnout, relação sofrimento-prazer, satisfação-insatisfação no trabalho, exposição ao vírus da imunodeficiência humana, e estratégias de proteção. Também, nessa fase, os estudos analisaram a relação entre o trabalho e a saúde dos trabalhadores, buscando seus determinantes. Ou seja, o quanto a geração de valor, concretizada nesse processo de trabalho, expõe os trabalhadores às diferentes cargas de trabalho e aos seus subsequentes desgastes, geradores de perfis de morbidade característicos. Nessa perspectiva, os estudos proporcionaram maior visibilidade dos problemas de saúde como pertencentes ao coletivo dos trabalhadores e, não mais, processos individuais; avançando, portanto, do biológico ao social.

Atualmente, os estudos identificam mudanças no perfil de morbidade dos trabalhadores de enfermagem, entre essas, os distúrbios musculoesqueléticos e os transtornos mentais e comportamentais, como depressão, transtornos de ansiedade e bipolares, entre outros. Esse perfil decorre das mudanças dos processos produtivos, da intensificação e da piora das condições de trabalho. No entanto, também apontam que as medidas preventivas não foram, ou foram pouco resolutivas, para os problemas de saúde anteriormente apontados.

Assim, a incidência de acidentes com exposição a fluidos corpóreos parece ter diminuído o que não se pode afirmar porque esses são pouco notificados; as doenças infecciosas, da mesma forma, não são integralmente notificadas e, quando o são, os afastamentos se dão por licença médica e não por acidente de trabalho, descaracterizando a relação de subordinação entre o trabalho e os problemas de saúde do trabalhador. Nessa situação, existe um comprometimento ético que desrespeita o trabalhador nos direitos de cidadão - o direito à saúde.

Evidencia-se, portanto, a coexistência de problemas de saúde, antigos e atuais, que são incrementados à medida que não são implantadas medidas resolutivas.

Nesse contexto, o conhecimento gerado permite apreender que o diagnóstico já existe - os problemas de saúde dos trabalhadores de enfermagem são conhecidos. Agora, é necessário haver intervenção e avaliação. Muitas propostas já foram feitas, porém poucas foram executadas, e quase nenhuma foi avaliada; isto porque ainda são incipientes estudos que propõe a avaliação das medidas preventivas introduzidas. Nesse cenário, a tecnologia pode favorecer tanto para a avaliação, como para o monitoramento contínuo da saúde do trabalhador de enfermagem.

Apesar da emergência, poucas experiências têm sido levadas a termo. Uma dessas propostas é o Sistema de Monitoramento da Saúde do Trabalhador de Enfermagem - SIMOSTE, o qual foi desenvolvido, implementado e avaliado pelo grupo de pesquisa Estudos Sobre a Saúde do Trabalhador de Enfermagem (CNPq). O SIMOSTE capta os determinantes da saúde e suas consequências, transformando dados em indicadores, com vistas a monitorar a saúde do trabalhador, mediante a operacionalização de estratégias preventivas para a melhoria de suas condições de saúde. Este Sistema de Monitoramento é utilizado em diferentes regiões brasileiras e seus resultados mostram o quanto a inovação tecnológica pode ser usada a favor do trabalhador. Para tanto, é necessária a vontade política de realizar as mudanças prementes.

${ }^{1}$ Enfermeira. Doutora em Enfermagem. Professora do Departamento de Orientação Profissional da Escola de Enfermagem da Universidade de São Paulo. Líder do Grupo de Pesquisa Estudos sobre a Saúde do Trabalhador de Enfermagem. 


\title{
THE NEED TO MONITOR THE HEALTH OF NURSING PERSONNEL
}

\author{
Vanda Elisa Andres Felli ${ }^{1}$
}

The production of knowledge on the study object The Health of Nursing Personnel has been increasing ever since the 1970's.

The first studies mainly diagnosed the incidence/prevalence of work accidents involving this population, as well as the different types of accidents and occupational risks to which nursing personnel are exposed. At that time, the high frequency of work accidents was identified, along with their characterization; the emphasis was on accidents with sharp injuries materials. Nevertheless, the studies undertaken disappoint in that they did not manage to include diseases such as hepatites and tuberculosis, which were not even considered to be related to the work, or the relationship was rarely proven. In addition to these issues, not even the lower back pains, so frequently found, were related to the nursing work.

Subsequent studies focussed on other health problems, showing that even though under the law they were not considered as being acquired in the work, the analysis of the work conditions and the high frequency of the health problems - as well as rates of comparison with other workers alone - provided evidence of the relationship. Among these one finds stress, Burnout syndrome, the relationships between suffering-pleasure and satisfaction-dissatisfaction at work, exposure to human immunodeficiency virus, and strategies of protection. Also in this phase, the studies analyzed the relationship between the work and the workers' health, seeking its determinants. That is, how much the production of value, made real in this process of work, exposes the workers to the different workload and to the subsequent strain, creating characteristic profiles of morbidity. In this perspective, the studies afforded greater visibility to the health problems as belonging to the collective of the workers; no longer were they individual processes. There was, therefore, an advance from the biological to the social.

Currently, the studies are identifying changes in nursing workers' profile of morbidity, including musculoskeletal disorders and the mental and behavioral disorders, such as depression, anxiety and bi-polar disorders, among others. This profile results from the changes in the productive processes, from the intensification and the worsening of the work conditions. They also, however, indicate that the preventive measures were not, or were little, resolutive, for the health problems indicated above.

Hence, the incidence of accidents involving exposure to body fluid seems to have reduced, which cannot be confirmed because these are little reported; the infectious illnesses, in the same way, are not fully reported, and when they are, the member of staff's absence from the workplace is done under 'medical leave' rather than 'work accident', which de-characterizes the relationship of subordination between the work and the worker's health problems. In this situation, there is an ethical commitment which disrespects the worker in his or her rights as a citizen - the right to health.

There is, therefore, evidence of the co-existence of health problems, both past and current, which increase as resolutive measures are not implanted.

In this context, the knowledge created allows one to grasp that the diagnosis already exists - the health problems of nursing personnel are known. What are needed now are interventions and evaluations. Many have been the proposals made, but few have been put into practice, and almost none, evaluated; this, because studies proposing to assess the preventive measures introduced remain incipient. In this scenario, technology can benefit both evaluation and the continuous monitoring of the nursing worker's health.

In spite of the emergency, few experiments have been carried through to their conclusion. One such proposal is the System for Monitoring Nursing Workers' Health - SIMOSTE, in Portuguese - which was developed, implemented and evaluated by the research group Studies on the Health of Nursing Workers (registered by the National Council of Technological and Scientific Development - CNPq). The SIMOSTE identifies the determinants of health and their consequences, transforming data into indicators, so as to monitor the worker's health, through the operationalization of preventive strategies for the improvement of their health conditions. This monitoring system is used in various regions of Brazil, and its results show how much technological innovation can be used to benefit the worker. For this, one needs the political will to make the necessary changes.

'Nurse. Doctorate in Nursing. Professor of the Career Guidance Department of the University of São Paulo's School of Nursing. Leader of the Studies on the Health of Nursing Workers Research Group.

Cogitare Enferm. 2013 Jul/Set; 18(3):429-31 


\section{LA NECESIDAD DE ACOMPAÑAMIENTO DE LA SALUD DEL TRABAJADOR DE ENFERMERÍA}

Vanda Elisa Andres Felli ${ }^{1}$

A partir de la década de 1970, pasa a se desarrollar de manera más efectiva la producción de conocimiento sobre el objeto de estudio Salud del Trabajador de Enfermería.

Los primeros estudios evidenciaron, principalmente, la incidencia/prevalencia de los accidentes de trabajo con esa población, así como los distintos tipos de accidentes y riesgos ocupacionales a que los trabajadores de enfermería están expuestos. En aquél momento, fueron identificadas las altas frecuencias de los accidentes de trabajo y su caracterización; pero el énfasis fue dado a los accidentes con materiales cortantes. Los estudios realizados decepcionan por el hecho de no considerar enfermedades, como hepatitis y tuberculosis, las cuales no eran relacionadas al trabajo o difícilmente se comprobaba esa relación. Además de esos agravios, ni las lumbalgias eran asociadas al trabajo en enfermería.

Estudios subsiguientes enfatizaron otros problemas de salud, revelando que a pesar de que legalmente no se los consideraba como adquiridos en el trabajo, el análisis de las condiciones de trabajo y la alta frecuencia de problemas de salud, así como los índices de comparación con otros trabajadores evidenciaban esa relación. Entre esos problemas, estrese, síndrome de Burnout, relación sufrimiento-placer, satisfacción-insatisfacción en trabajo, exposición al virus de la inmunodeficiencia humana y estrategias de protección. En esa fase, los estudios también analizaban la relación entre el trabajo y la salud de los trabajadores, buscando sus determinantes, es decir, lo cuanto la generación de valor, concretizada en ese proceso de trabajo, expone los trabajadores a distintas cargas y a los conseguientes desgastes, generadores de perfiles de morbidez característicos. En esa perspectiva, los estudios proporcionaron más visibilidad de los problemas de salud como pertenecentes al colectivo de los trabajadores y no más a procesos individuales; avanzando, por tanto, del biológico al social.

Actualmente, los estudios identifican cambio en el perfil de morbidez de los trabajadores de enfermería, entre esos, los disturbios osteomusculares y los trastornos mentales y de comportamiento, como depresión, trastornos de ansiedad y bipolares, entre otros. Ese perfil viene de los cambios de los procesos productivos, así como de la intensificación y de la degradación de las condiciones de trabajo. Sin embargo, también apuntan que las medidas preventivas no fueron, o poco fueron satisfactorias para los problemas de salud anteriormente apuntados.

De ese modo, la incidencia de accidentes con exposición a fluidos corpóreos parece disminuir, lo que no se puede decir porque esos son poco notificados; las enfermedades infecciosas, de la misma forma, no son integralmente notificadas y, cuando eso ocurre, los apartamientos son por licencia médica y no por accidente de trabajo, descaracterizando la relación de subordinación entre el trabajo y los problemas de salud del trabajador. En esa situación, hay un comprometimiento ético que no respeta el trabajador en los derechos de ciudadanos - el derecho a la salud.

Se evidencia, por lo tanto, la coexistencia de problemas de salud, antiguos y actuales que son incrementados a proporción que no son implantadas medidas resolutivas.

En ese contexto, el conocimiento generado permite comprender que el diagnóstico ya existe - los problemas de salud de los trabajadores de enfermería son conocidos. Sin embargo, son necesarias una intervención y una evaluación. Muchas propuestas fueron hechas, pero pocas fueron ejecutadas, siendo casi ninguna evaluada porque todavía son incipientes los estudios que proponen evaluación de las medidas preventivas introducidas. La tecnologia puede favorecer esa cuestión tanto para la evaluación cuanto para el acompañamiento continuo de la salud del trabajador de enfermería.

A pesar de la emergencia, pocas experiencias son concretizadas. Una de las propuestas es el Sistema de Acompañamiento (Monitoramento) de la Salud del Trabajador de Enfermería - SIMOSTE, lo cual fue desarrollado, implementado y evaluado por el grupo de investigación Estudios sobre la Salud del Trabajador de Enfermería (CNPq). El SIMOSTE capta los determinantes de la salud y sus consecuencias, transformando datos en indicadores, con la finalidad de verificar y acompañar la salud del trabajador por medio de estrategias preventivas para mejorar sus condiciones de salud. Este Sistema es utilizado en distintas regiones de Brasil y sus resultados muestran lo cuanto la innovación tecnológica puede ser usada en beneficio del trabajador. Pero, para eso, es imprescindible la voluntad política de realizar los cambios necesarios.

${ }^{1}$ Enfermera. Doctora en Enfermería. Profesora del Departamento de Orientación Profesional de la Escuela de Enfermería de la Universidad de São Paulo. Líder del Grupo de Investigación de Estudios sobre la Salud del Trabajador de Enfermería. 